\title{
Xylanases from Streptomyces cyaneus: their production, purification and characterization
}

\author{
P. Wang, J. Clark Mason and Paul Broda* \\ Department of Biochemistry \& Applied Molecular Biology, University of Manchester Institute of Science \& \\ Technology, PO Box 88, Manchester M60 1QD, UK
}

(Received 20 August 1992; revised 26 April 1993; accepted 7 May 1993)

\begin{abstract}
Streptomyces cyaneus produces extracellular xylanases in good yield when grown on ball-milled straw and xylan. Ball-milled straw induced nearly twice as much of these activities as did xylan, but phenolic substances released from the straw impeded purification of enzymes. Three extracellular xylanases, I, II and III, were identified in xylan-grown culture supernatants. Xylanases I and II were each purified to give single bands by SDS-PAGE. They had $M_{\mathrm{r}}$ values of 37500 and 34000 respectively, while that of III was apparently 45000 . pI values were $5 \cdot 1$ (I) and 5.3 (II) while $\mathrm{pH}$ and temperature optima, in $10 \mathrm{~min}$ assays, were $8 \cdot 5,72^{\circ}$ (I) and $6.5,65^{\circ} \mathrm{C}$ (II).
\end{abstract}

\section{Introduction}

We have studied the abilities of three actinomycetes, Actinomadura sp., Thermomonospora mesophila and Streptomyces cyaneus, to solubilize lignocellulose (Mason, 1988; Zimmermann \& Broda, 1989; Broda et al., 1989). Of the three strains, $S$. cyaneus had the best growth characteristics, and it produced $\left[{ }^{14} \mathrm{C}\right.$-lignin $]-$ lignocellulose solubilization activity earlier and in greater yield than did the other two strains (Mason et al., 1988).

In plants, lignin, cellulose and hemicellulose are closely associated; hemicelluloses (especially xylans) and lignin are cross-linked by various covalent bonds (Timell, 1967). Hydrolysis of xylan facilitates the removal of lignin from biomass. Thus xylan-degrading enzymes are increasingly being used in biobleaching of pulps for paper manufacture (Buchert et al., 1992). For this reason we began an investigation of xylan-degradation by $S$. cyaneus.

When the organism is grown on ball-milled straw, substantial amounts of acid-precipitable (phenolic) materials are produced, making the isolation of extracellular proteins so difficult that the cellulase, xylanase and $\left[{ }^{14} \mathrm{C}\right]$ lignocellulose solubilization activities cannot readily be characterized (Mason et al., 1988). The experiments described here define better conditions for the production and isolation of proteins involved in xylan conversion.

\footnotetext{
*Author for correspondence. Tel. (061) 2004203 ; fax (061) 236 0409 .
}

\section{Methods}

Organism, media and culture conditions. Streptomyces cyaneus MT813 (McCarthy \& Broda, 1984; Mason et al, 1988) was cultured in a medium containing $\left(\mathrm{l}^{-1}\right) 0.1 \mathrm{~g}\left(\mathrm{NH}_{4}\right)_{2} \mathrm{SO}_{4}, 0.3 \mathrm{~g} \mathrm{NaCl}, 0.1 \mathrm{~g} \mathrm{MgSO}$, $0.2 \mathrm{~g} \mathrm{CaCO}_{3}, 1 \mathrm{~g}$ Bacto yeast extract, and $1 \mathrm{ml}$ trace elements $(0.02 \%$ $\mathrm{FeSO}_{4} .7 \mathrm{H}_{2} \mathrm{O}, 0.018 \% \mathrm{ZnSO}_{4} .7 \mathrm{H}_{2} \mathrm{O}$ and $0.002 \% \mathrm{MnSO}_{4} .4 \mathrm{H}_{2} \mathrm{O}$ ). The medium was adjusted to $\mathrm{pH} 7.0$ with $\mathrm{Na}_{2} \mathrm{HPO}_{4}$. The carbon sources listed in Table 1 were used at final concentrations of $0.2 \%$. Cultures were inoculated with spore suspensions and incubated at $37^{\circ} \mathrm{C}$ with shaking at 150 r.p.m.

Preparation of ball-milled straw. Chopped cereal straw and ballbearings at $1: 1(\mathrm{v} / \mathrm{v})$ were packed into the ball-milling chamber of a Siebertechnik ball-mill and milled for $72 \mathrm{~h}$ at room temperature. The ground material was sieved through a 60 mesh sieve to remove large particles before use.

Bicinchoninate reagent. Reducing sugar concentrations were assayed using the bicinchoninate $/ \mathrm{Cu}^{2+}$ reagent and a procedure adapted from Mopper \& Gindler (1973) and Sinner \& Puls (1978). The reagent was prepared as follows. Solution A contained disodium 2,2'bicinchoninate $(0.65 \mathrm{~g})$, sodium carbonate (anhydrous; $0.36 \mathrm{~g})$, distilled water to $500 \mathrm{ml}$. Solution B contained aspartic acid (3.7 g), sodium carbonate (anhydrous; $5.0 \mathrm{~g}$ ), copper(II) sulphate (anhydrous; $1 \mathrm{~g}$ ), distilled water to $150 \mathrm{ml}$. Copper(II) sulphate was first dissolved in $40 \mathrm{ml}$ water and then mixed with the solution of aspartic acid and sodium carbonate. Before use, $A$ and $B$ were combined in a ratio of $23: 1(\mathrm{v} / \mathrm{v})$.

Preparation of xylan suspension. Remazol brilliant blue xylan (RBBxylan) was prepared according to Biely el al. (1985). Oatspelt arabinoglucuronoxylan (Sigma) suspension was prepared as described by Wang \& Broda (1992); this involved two centrifugations, one to remove larger particles and the other to remove soluble xylan. For routine assays suspensions contained $4 \mathrm{mg}$ xylan $\mathrm{ml}^{-1}$. Arabinogalactan (larchwood, Sigma), a polysaccharide with a $\beta$-1,3-linked main chain, was prepared in the same way.

Enzyme assays. Xylan-degrading activity was measured by a procedure adapted from Zimmermann et al. (1988). Enzyme $(25 \mu \mathrm{l})$ 
was mixed with $75 \mu \mathrm{l}$ of the xylan ( $4 \mathrm{mg} \mathrm{ml}^{-1}$ ) suspension prepared as described above in barbital buffer ( $25 \mathrm{~mm}$ ) $\mathrm{pH} 7 \cdot 8$ and the mixture was incubated at $60^{\circ} \mathrm{C}$ for $10 \mathrm{~min}$. At the end of the incubation the mixture was cooled quickly in an ice-water bath. Bicinchoninate $/ \mathrm{Cu}^{2+}$ reagent $(1 \mathrm{ml})$ was added to the reaction mixture and incubated at $80^{\circ} \mathrm{C}$ for $10 \mathrm{~min}$. The reaction was cooled again in an ice-water bath and the absorbance at $562 \mathrm{~nm}$ was determined. Appropriate controls were included in all assays. All assays were carried out in $1.5 \mathrm{ml}$ microcentrifuge tubes. One unit (U) of xylanase is defined as the amount of enzyme that releases $1 \mu \mathrm{mol}$ of xylose equivalent $\min ^{-1}$ under the above conditions.

$\beta$-Glycosidase activity was measured by determining the amount of $p$-nitrophenol (pNP) or $o$-nitrophenol (oNP) released from the appropriate substrates. Substrates were dissolved in distilled water at concentrations of $10 \mathrm{mM}$. The reaction mixture contained $50 \mu \mathrm{l}$ of enzyme preparation, $50 \mu \mathrm{l}$ of substrate and $50 \mu \mathrm{l}$ of $50 \mathrm{~mm}$-sodium barbital buffer, $\mathrm{pH} 7 \cdot 8$. After incubation at $37^{\circ} \mathrm{C}, 1 \mathrm{ml} 1 \mathrm{M}-\mathrm{Na}_{2} \mathrm{CO}_{3}$ was added to the enzyme reaction mixture and the absorbance at $400 \mathrm{~nm}$ (for pNP) or $420 \mathrm{~nm}$ (for oNP) was determined immediately.

Hydrolysis of arabinogalactan was assayed by incubating $25 \mu 1$ of the enzyme preparation with $75 \mu \mathrm{l}$ of an arabinogalactan suspension ( $4 \mathrm{mg} \mathrm{ml}^{-1}$ ) in $25 \mathrm{~mm}$-sodium barbital buffer, $\mathrm{pH} 7.8$ at $37^{\circ} \mathrm{C}$ overnight. Reducing sugar produced was measured with the bicinchoninate $/ \mathrm{Cu}^{2+}$ reagent.

Cellulase activity was assayed by incubating $25 \mu$ of enzyme with $75 \mu 1$ of a $2 \%(\mathrm{w} / \mathrm{v})$ suspension of microcrystalline cellulose in $10 \mathrm{~mm}-$ maleate, $\mathrm{pH} 5.4$, at $37^{\circ} \mathrm{C}$ overnight. After incubation the undigested substrate was removed by centrifugation at $12000 \mathrm{~g}$ for $5 \mathrm{~min}$. The reducing sugar content of the supernatant was measured by the bicinchoninate/ $\mathrm{Cu}^{2+}$ method.

Hydrolysis of RBB-xylan was determined by the release of dye to the supernatant following precipitation of undigested substrate by different amounts of $2 \mathrm{M}-\mathrm{NaCl}$ (unpublished results).

Determination of protein concentration. Protein concentration was measured by the method of Bradford (1976). A sample $(800 \mu \mathrm{l})$ of protein containing $1-20 \mu \mathrm{g}$ protein was mixed with $200 \mu$ of dye (BioRad) and allowed to stand at room temperature for $5 \mathrm{~min}$. The absorbance at $595 \mathrm{~nm}$ was determined and protein concentration was calculated by reference to a standard curve using suitabie dilutions of bovine serum albumin $\left(100 \mu \mathrm{g} \mathrm{ml}^{-1}\right.$; Sigma)

SDS-PAGE. Separation of proteins by SDS-PAGE was as described by Laemmli (1970). $M_{\mathrm{r}}$ values were determined by comparing the electrophoretic mobility of the unknown proteins with those of standards (Sigma). Gels were stained overnight at room temperature with Coomassie Brilliant Blue.

Stain for xylanase activity. After electrophoresis, the SDS gel was soaked in $20 \mathrm{~mm}$-Tris $/ \mathrm{HCl}, \mathrm{pH} 7.5$, containing $0.7 \%$ Triton $\mathrm{X}-100$ with gentle shaking for $1 \mathrm{~h}$. The procedure was repeated twice. Gels were then incubated with $20 \mathrm{mM}$-Tris $/ \mathrm{HCl}, \mathrm{pH} 7 \cdot 5$, for $20 \mathrm{~min}$, washed with distilled water, and incubated with a $0.1 \%$ xylan suspension at $37^{\circ} \mathrm{C}$ for $2 \mathrm{~h}$. The gel was washed again with distilled water, stained with Congo Red $\left(0.5 \mathrm{mg} \mathrm{ml}^{-1}\right)$ for $15 \mathrm{~min}$, and then destained in $1 \mathrm{M}$ $\mathrm{NaCl}$ for at least $15 \mathrm{~min}$. Xylanase bands were yellow and the background was red. The gel was photographed within a few hours or was treated with $1 \mathrm{M}-\mathrm{HCl}$ for longer storage. After acidification the xylanase bands were white against a blue blackground.

Isoelectric focusing. Isoelectric focusing was performed in $5 \%(\mathrm{w} / \mathrm{v})$ polyacrylamide gels $(150 \times 180 \times 0.75 \mathrm{~mm})$. Gels were stained for protein as above.

Preparation of dialysate for purifying xylanases. Protein in the culture filtrate was precipitated by addition of $\left(\mathrm{NH}_{4}\right)_{2} \mathrm{SO}_{4}$ to $60 \%$ saturation.
The precipitate was dissolved in $20 \mathrm{~mm}$-Tris/ $\mathrm{HCl}$ buffer, $\mathrm{pH} 7.5$, and dialysed overnight against $20 \mathrm{~mm}$-sodium acetate, $\mathrm{pH} 50$. The dialysate was centrifuged in a bench-top centrifuge. The supernatant was used for isolation of xylanase II and the precipitate was dissolved in $20 \mathrm{~mm}$ Tris $/ \mathbf{H C l}, \mathrm{pH} 7.5$ for isolation of xylanase I.

Purification of xylanase I. QAE-Sephadex pre-equilibrated in $20 \mathrm{mM}$ Tris $/ \mathrm{HCl}, \mathrm{pH} 7 \cdot 5$, was added to the dialysate to a final concentration of $1 \mathrm{mg} \mathrm{ml} \mathrm{m}^{-1}$. The QAE-Sephadex (where the bulk of the phenolic pigments adsorbed) was filtered away and the filtrate was then loaded on a DEAE-Sepharose column $(1.5 \times 15 \mathrm{~cm})$. The column was equilibrated with $20 \mathrm{mM}-\mathrm{Tris} / \mathrm{HCl}, \mathrm{pH} 7.5$, and protein was eluted using $100 \mathrm{ml}$ of a linear gradient $(0-0.65 \mathrm{M})$ of $\mathrm{Na}_{2} \mathrm{SO}_{4}$ in the same buffer.

Purification of xylanase II. The protein precipitated with $\left(\mathrm{NH}_{4}\right)_{2} \mathrm{SO}_{4}$ was dissolved in and dialysed against $50 \mathrm{~mm}$-acetate buffer, $\mathrm{pH} 50$, then loaded on a DEAE-Sepharose column $(1.6 \times 35 \mathrm{~cm})$. Protein was eluted with a gradient from $0 \%$ to $65 \%$ of $1 \mathrm{M}-\mathrm{NaCl}$ in $50 \mathrm{~mm}$-acetate buffer, $\mathrm{pH} 5 \cdot 0$. Fractions containing the major xylanase activity (fractions 4 to 14) were collected and de-salted using a column of Sephadex G25.

The pooled partially purified xylanase samples eluted from DEAESepharose were freeze-dried and loaded on a MonoQ column. The column was eluted with an $\mathrm{NaCl}$ gradient $(0 \%$ to $65 \%$ of a $1 \mathrm{M}-\mathrm{NaCl}$ solution in $20 \mathrm{ml} 20 \mathrm{mM}$-Tris/HCl, $\mathrm{pH} 7.5$ )

\section{Results}

\section{Effect of carbon source}

The yields of xylanase activity on various carbon sources were compared with that given by growth on ball-milled straw. Neither monosaccharides nor disaccharides induced activity, while each of the polysaccharides did (Table 1). Of the latter, xylan was the best. Because of the difficulties associated with production of a pigment when ball-milled straw was used as substrate, xylan-grown culture filtrates were used in all subsequent investigations.

Production of xylanase activity was 2-3-fold higher in ball-milled straw than in xylan media. However, cul-

Table 1. Effect of carbon source on the production of xylanase activities

\begin{tabular}{lc}
\hline \hline Carbon & $\begin{array}{c}\text { Mean } \\
\text { xylanase } \\
\text { activity } \\
\left(\mathrm{mU} \mathrm{ml}^{-1}\right)\end{array}$ \\
source & 29 \\
CM cellulose & 39 \\
Cellulose MN-300 & 29 \\
Soluble starch & $145(3)$ \\
Oatspelt xylan & $269(3)$ \\
Ball-milled straw & 269 \\
\hline \hline
\end{tabular}

D-Glucose, D-xylose, lactose, maltose and cellobiose all gave values of $<0.001$. Data labelled (3) are the means from triplicate experiments; other data are the means of duplicates. All the samples were taken at $96 \mathrm{~h}$. 


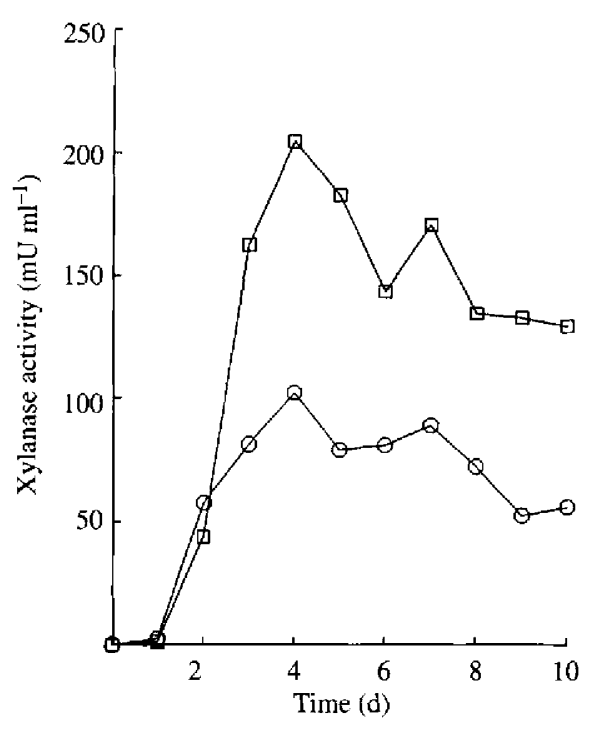

Fig. 1. Variation in xylanase activities produced by $S$. cyaneus grown for $10 \mathrm{~d}$ in a medium containing either $0.2 \%$ xylan $(O)$ or $0.2 \%$ BMS ( $\square$ ) with shaking at $37^{\circ} \mathrm{C}$.

tivation in either medium was characterized by marked peaking and troughing of activity (Fig. 1). The phenomenon has been noted before in xylanase production by Talaromyces emersonii (Tuohy \& Coughlan, 1992). There the peaking and troughing was attributed to differences in the timing of induction of separate components of the xylanase system - the products of action of one component inducing the synthesis of another, and so on - as well as to differential inactivation by proteases, or variation in the $\mathrm{pH}$ during uncontrolled cultivation conditions. The growth conditions reported here were not $\mathrm{pH}$-controlled but the $\mathrm{pH}$ rose only from an initial 7.0 to 7.8 at harvest.

Samples of culture filtrates clarified agar gels containing $1 \%$ oatspelt xylan suspension. They also catalysed a rapid decrease in the turbidity of a $1 \%$ oatspelt xylan suspension (Wang \& Broda, 1992). Moreover, such samples released dye from RBB-xylan. These findings indicate that the filtrates of xylan-grown cultures contain endo- $\beta$-1,4-xylanase activity, i.e. they catalyse hydrolysis of the oatspelt arabinoxylan backbone (Biely et al., 1985).

\section{Effect of $\mathrm{pH}$, temperature and salts on xylanase activity}

Xylanase activity in culture filtrates, as measured by the release of reducing sugars from suspensions of oatspelt arabinoxylan, was detected over a broad $\mathrm{pH}$ range (3-9) but was optimal at $\mathrm{pH} 7.8$ in 10 min assays. Reducing

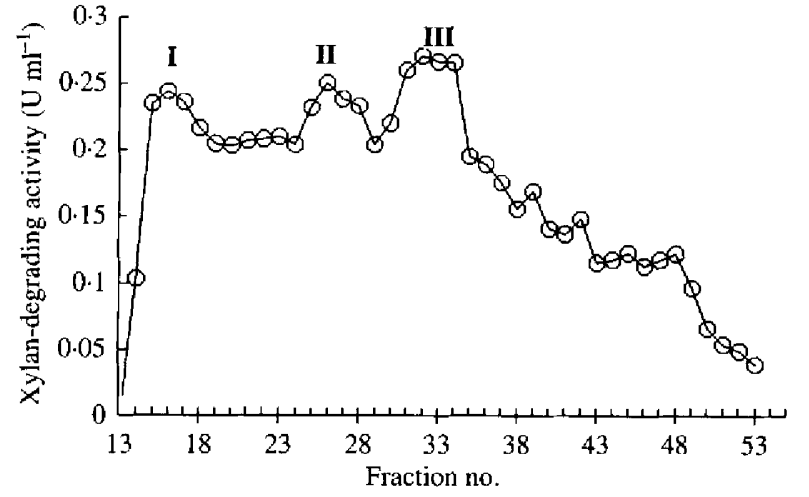

Fig. 2. Distribution of xylan-degrading activity in $0.5 \mathrm{ml}$ fractions obtained by gel filtration on Superose 12 of extracellular proteins produced by $S$. cyaneus grown in a medium containing xylan.

sugar production from this substrate by crude filtrates was detected at temperatures ranging from $20-80^{\circ} \mathrm{C}$ and was optimal at $60^{\circ} \mathrm{C}$.

Xylanase activities in crude filtrates in barbital or phosphate buffers were higher than that in Tris/HCl buffer. Routine assays of such activity in subsequent investigations were therefore carried out at $60^{\circ} \mathrm{C}$ in 25 mM-barbital buffer, $\mathrm{pH} 7 \cdot 8$.

\section{Separation of xylanase activities by gel filtration and $S D S-P A G E$}

Filtrates of 4-d-old xylan-grown cultures were subjected to FPLC gel filtration on Superose 12. Major peaks of activity (peaks I, II and III) were found in fractions 16 , 27 and 34 (Fig. 2). The materials in these fractions were analysed using the zymogram technique for xylanase activity. The corresponding $M_{\mathrm{r}}$ values were calculated to be 37500,34000 and 45000 respectively. The fact that the three enzyme activities were not eluted in order of decreasing $M_{\mathrm{r}}$ value, as ideally they would be, may reflect interaction with the column matrix.

\section{Purification of xylanase I}

By a four-step procedure, FPLC gel filtration, precipitation, QAE-Sephadex adsorption and anion exchange chromatography (Fig. $3 a$ ), $430 \mu \mathrm{g}$ of xylanase I was obtained from $1700 \mathrm{ml}$ of culture filtrate. By SDSPAGE this preparation gave only one visible band with an $M_{\mathrm{r}}$ of 37500 ; a zymogram showed that the $M_{\mathrm{r}} 37500$ protein was the only xylan-solubilizing activity in that preparation (Fig. $3 b$ ). Efficient degradation of xylan is effected by the synergistic interaction of side-chains and main-chain hydrolysing activities. Fractionation of such components would disrupt the potential for such synergy. 


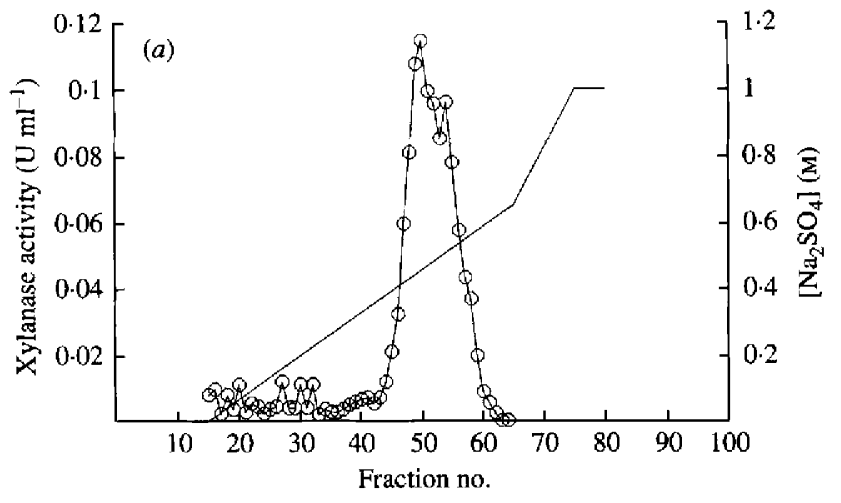

(b)

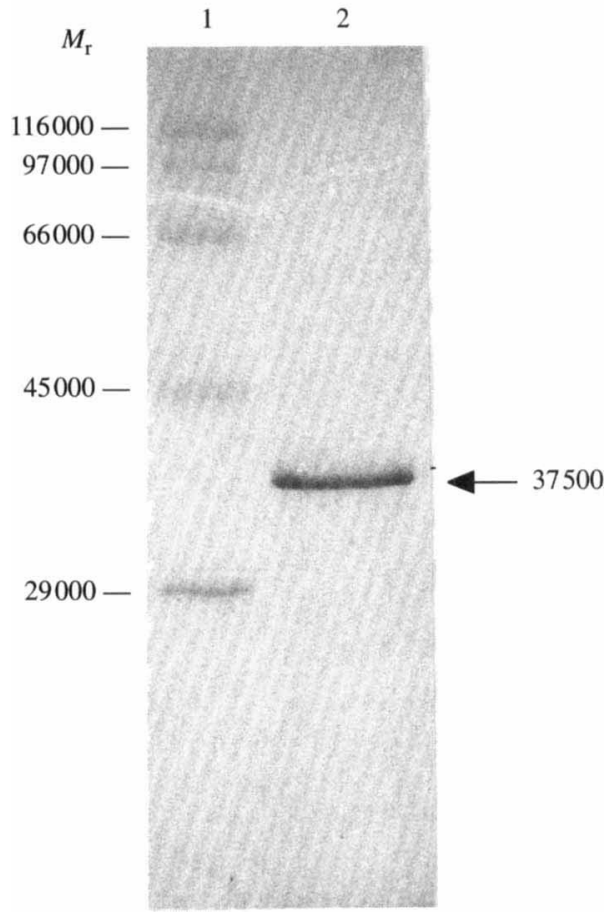

Fig. 3. (a) Separation of xylanase I activity $(O)$ by anion exchange chromatography on DEAE-Sepharose. The column had a bed volume of $35 \mathrm{ml}$. Approximately $4.4 \mathrm{mg}$ protein was loaded, then eluted with a sodium sulphate gradient ( $\longrightarrow$ ) in $20 \mathrm{mM}-\mathrm{Tris} / \mathrm{HCl}$, $\mathrm{pH}$ 7.5. Fraction size : $2 \mathrm{ml}$. Flow rate: $1 \mathrm{ml} \mathrm{min}^{-1}$. (b) SDS-PAGE of xylanase I. A $15 \mu \mathrm{g}$ sample of a preparation obtained after anion exchange chromatography on DEAE-Sepharose was loaded on the gel. Lane 1, $M_{\mathrm{r}}$ markers; lane 2, xylanase 1 .

This would explain why the recovery of xylanase activity was low (Table 2). Nevertheless, the procedure gave an enzyme preparation without detectable contamination by other xylanases and suitable for further characterization.

\section{Purification of xylanase II}

Xylanase II was purified by a different four-step procedure involving filtration, precipitation and two cycles of anion exchange chromatography (Fig. 4 and Table 2). After the last step the enzyme preparation (fraction 9 to 13 , Fig. $4 b$ ) contained only one protein by SDS-PAGE analysis: when the gel was stained for xylanase activity, a single band corresponding to that stained for protein was detected. The $M_{\mathrm{r}}$ was estimated to be 34000 (Fig. $4 c$ ).

The $\mathrm{pI}$ values of purified preparations of xylanases I and II were determined by isoelectric focusing to be $5 \cdot 1$ and 5.2 respectively. Xylanases I and II were optimally active at $72{ }^{\circ} \mathrm{C}$ and $65^{\circ} \mathrm{C}$, respectively. Xylanase I catalysed the liberation of reducing sugars from xylan at $\mathrm{pH}$ values ranging from $4 \cdot 0$ to $10 \cdot 5$. Activity was optimal at $\mathrm{pH} 8.0$ and was $80 \%$ of the optimum at $\mathrm{pH} 6.0$ and at $\mathrm{pH} 10.5$. Xylanase II showed activity at all $\mathrm{pH}$ values tested between 3.0 and 10 ; the optimum $\mathrm{pH}$ value was 6.5 , and activity was $80 \%$ of optimum at pH 5.5 and 7.5 (Fig. 5).

\section{Substrate specificity}

Each of the purified proteins catalysed the release of dye from RBB-xylan. Thus, they are endoxylanases or exhibit endoxylanase activity, i.e. they cleave the $\beta$-1,4-linked backbone of oatspelt arabinoxylan. In long-term incubations $\left(37^{\circ} \mathrm{C}\right.$ overnight) both proteins liberated reducing sugars from arabinoxylan and type II arabinogalactan, a $\beta$-1,3-linked polymer of $\beta$-D-galactopyranose with 6linked $\beta$-D-galactopyranosyl and $\alpha$-L-arabinofuranosyl initiated side-chains. Neither enzyme had detectable action against cellulose. Each protein could be differentiated by its actions against artificial substrates (Table 3). Xylanase I acted significantly against the pNP derivative of $\alpha$-L-arabinofuranoside. By contrast, xylanase II lacked this activity. Xylanase II has activity against pNP derivatives of $\beta$-D-mannopyranoside but xylanase I lacks this activity. Further work, including identification 

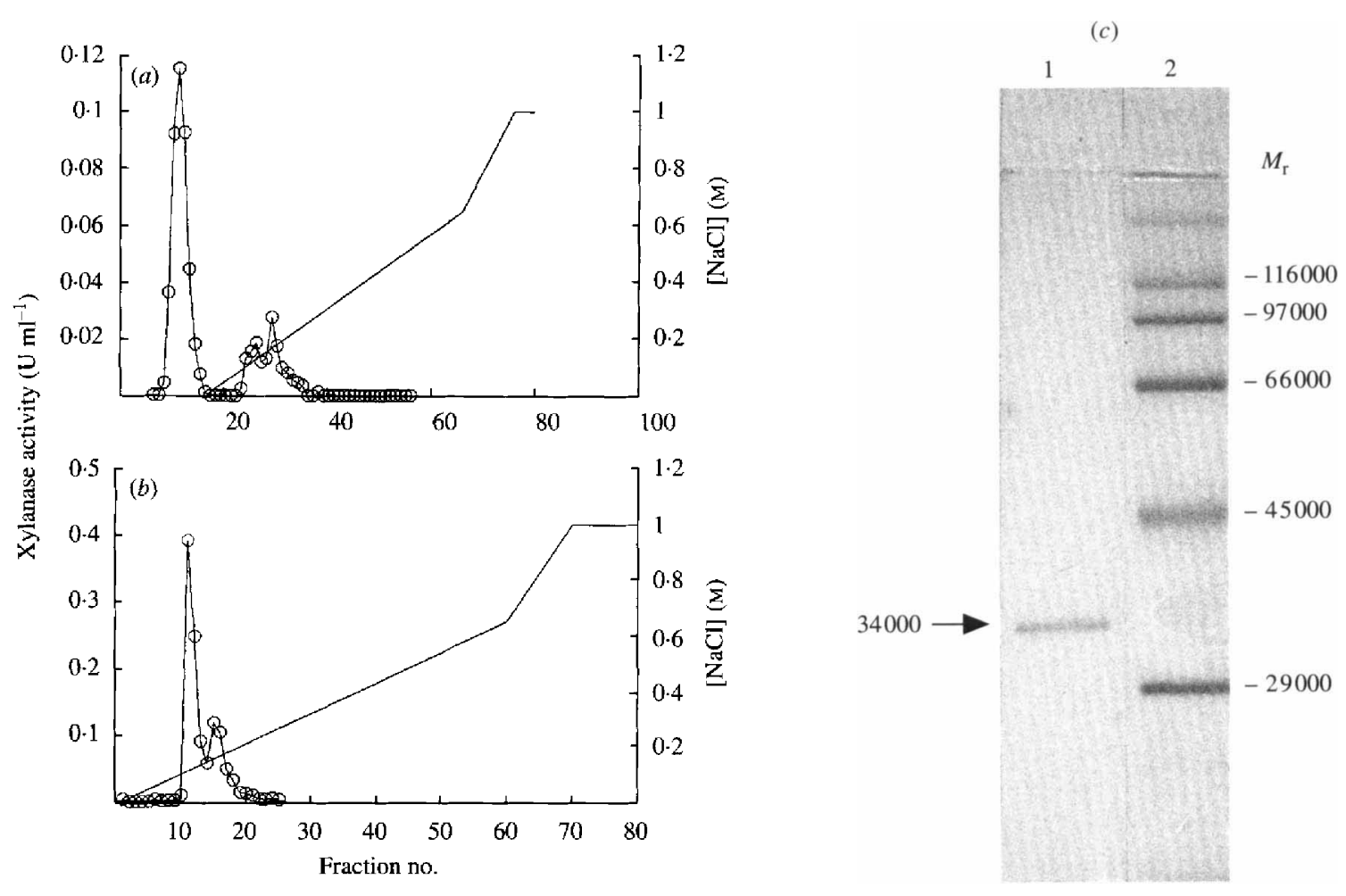

Fig. 4. (a) Separation of xylanase II activity (O) by anion exchange chromatography on DEAE-Sepharose. Approximately $0.5 \mathrm{mg}$ protein was loaded on the column. The protein was eluted with an $\mathrm{NaCl}$ gradient $(-)$ in $50 \mathrm{~mm}$-sodium acetate, pH 50 . Fraction size : $2 \mathrm{ml}$. Column bed volume: $35 \mathrm{ml}$. Flow rate: $1 \mathrm{ml} \mathrm{min}^{-1}$. (b) Separation of xylanase II activity by anion exchange chromatography on a MonoQ column. About $0.5 \mathrm{mg}$ protein was loaded. The protein was eluted with an $\mathrm{NaCl}$ gradient in $20 \mathrm{~mm}-\mathrm{Tris} / \mathrm{HCl}, \mathrm{pH} 7.5$. Fraction size: $0.5 \mathrm{ml}$. Flow rate: $1 \mathrm{ml} \mathrm{min}{ }^{-1}$. (c) SDS-PAGE of xylanase II. A $10 \mu \mathrm{g}$ sample of a preparation obtained after anion exchange chromatography on MonoQ was loaded on the gel. Lane 1, xylanase II; lane $2, M_{\mathrm{r}}$ markers.

Table 2. Purification of xylan-degrading activities I and II

\begin{tabular}{|c|c|c|c|c|c|c|c|}
\hline & \multirow[b]{2}{*}{ Filtrate } & \multicolumn{3}{|c|}{ Activity I } & \multicolumn{3}{|c|}{ Activity II } \\
\hline & & $\begin{array}{l}\text { Precipitated } \\
\text { with } \\
\text { ammonium } \\
\text { sulphate }\end{array}$ & $\begin{array}{c}\text { QAE } \\
\text { Sephadex } \\
\text { adsorption }\end{array}$ & $\begin{array}{c}\text { DEAE } \\
\text { Sepharose }\end{array}$ & $\begin{array}{l}\text { Precipitated } \\
\text { with } \\
\text { ammonium } \\
\text { sulphate }\end{array}$ & $\begin{array}{c}\text { DEAE } \\
\text { Sepharose }\end{array}$ & MonoQ \\
\hline Volume (ml) & 1700 & 50 & 40 & 14 & 50 & 240 & 18 \\
\hline $\begin{array}{l}\text { Xylanase } \\
\text { activity } \\
\left(\mathrm{mU} \mathrm{ml} \mathrm{m}^{-1}\right)\end{array}$ & 105 & 552 & 460 & 292 & 522 & 8 & $18 \cdot 4$ \\
\hline $\begin{array}{l}\text { Total } \\
\text { activity } \\
\text { (mU) }\end{array}$ & 178500 & 27600 & 18400 & 4088 & 26120 & 1920 & $33 t$ \\
\hline $\begin{array}{l}\text { Concentration } \\
\text { of protein } \\
\left(\mathrm{mg} \mathrm{ml}^{-1}\right)\end{array}$ & 75 & 208 & 112 & $30 \cdot 4$ & $61 \cdot 4$ & $4 \cdot 4$ & $8 \cdot 3$ \\
\hline $\begin{array}{l}\text { Total } \\
\text { protein } \\
\text { (mg) }\end{array}$ & 127 & $10 \cdot 4$ & $4 \cdot 4$ & $0 \cdot 43$ & 3.07 & 1.06 & 0.15 \\
\hline $\begin{array}{l}\text { Specific } \\
\text { activity } \\
{[\mathrm{mU}(\mathrm{mg}} \\
\left.\text { protein })^{-1}\right]\end{array}$ & 1400 & 2653 & 4182 & 9507 & 8502 & 1818 & 2207 \\
\hline $\begin{array}{l}\text { Percentage } \\
\text { recovery }\end{array}$ & 100 & $15 \cdot 4$ & $10 \cdot 3$ & $2 \cdot 3$ & $14 \cdot 6$ & $1 \cdot 1$ & 0.2 \\
\hline
\end{tabular}




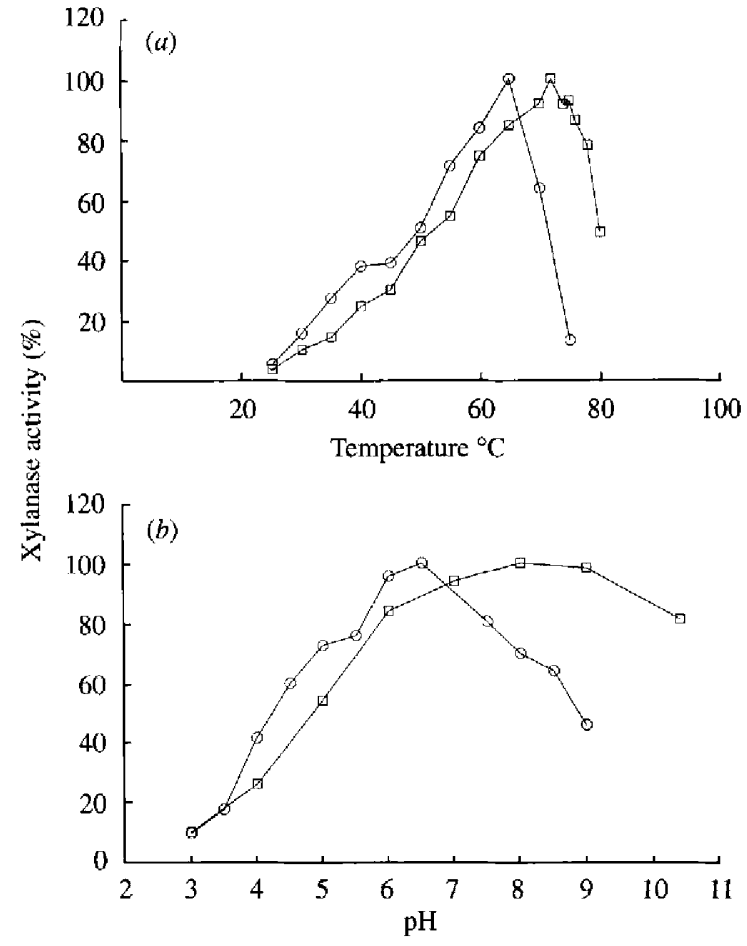

Fig. 5. Effect of temperature and $\mathrm{pH}$ on activities of xylanase $\mathrm{I}(\square)$ and xylanase II $(O)$, given as a percentage of the optimal activities. The incubation time for the enzyme reactions was $10 \mathrm{~min}$. (a) Effect of temperature; the incubation buffer was $0025 \mathrm{M}$-sodium barbital, $\mathrm{pH} 7.8$. (b) Effect of $\mathrm{pH}$. Three buffers were used for the enzyme activity assays: $0.025 \mathrm{M}$-sodium citrate, $\mathrm{pH} 3 \cdot 0,4 \cdot 0,5 \cdot 0,6 \cdot 0 ; 0.025 \mathrm{M}$-sodium barbital, $\mathrm{pH} 7 \cdot 0,8 \cdot 0$; and $0.025 \mathrm{M}$-glycine/sodium hydroxide, $\mathrm{pH} 9.0$, $10 \cdot 4$.

\section{Table 3. Relative activities of xylanases}

All values are means of duplicate assays with variations of less than $5 \%$. The percentages of the amounts of products produced were calculated by using xylan ('natural' substrates; upper part of table) or pNP- $\beta$-D-xylopyranoside ('artificial' substrates; lower part of table) as standard.

\begin{tabular}{lcc}
\hline \hline Substrate & $\begin{array}{c}\text { Xylanase I } \\
(\%)\end{array}$ & $\begin{array}{c}\text { Xylanase II } \\
(\%)\end{array}$ \\
\hline Xylan & 100 & 100 \\
Arabinogalactan & $17 \cdot 4$ & $9 \cdot 6$ \\
Cellulose-azure & 0 & 0 \\
$\begin{array}{c}\text { pNP- } \beta \text {-D- } \\
\text { xylopyranoside }\end{array}$ & 100 & 100 \\
pNP- $\beta$-D- \\
$\begin{array}{c}\text { galactopyranoside } \\
\text { pNP- } \beta \text {-D- } \\
\text { mannopyranoside } \\
\text { pNP- } \beta \text {-D- } \\
\text { glucopyranoside } \\
\text { pNP-L- } \\
\text { arabinofuranoside }\end{array}$ & $0 \cdot 82$ & $23 \cdot 2$ \\
\hline \hline
\end{tabular}

of the products of xylan degradation, will be required to determine the exact nature of the two enzymes.

\section{Discussion}

Streptomyces cyaneus was originally screened for its higher activity in degradation of lignin (McCarthy \& Broda, 1984). However, lignin is tightly combined with hemicellulose and cellulose so that micro-organisms are faced with a lignocellulose complex rather than a simple carbon source. Compared with organisms such as Bacillus and yeast, Streptomyces cyaneus is well-equipped for degradation of the lignocellulose complex.

With the eight substrates tested, the two xylanases that were purified showed different patterns of substrate specificity. Although the main activity of each was against xylan, both xylanases show activity to arabinogalactan. Furthermore, xylanase I showed very high activity against $\mathrm{pNP}-\beta$-D-xylopyranoside and significant activity against $\mathrm{pNP}-\alpha$-L-arabinofuranoside; xylanase II had lower activity against pNP- $\beta$-D-xylopyranoside and pNP- $\beta$-D-mannopyranoside and showed no activity against $\mathrm{pNP}-\alpha-\mathrm{L}$-arabinofuranoside.

Due to the complex pattern of the enzymes produced by $S$. cyaneus and the difficulties in purifying these proteins, contamination by other proteins cannot be completely ruled out; however, the purified proteins gave single bands on SDS-gels. Multifunctionality of enzymes is another possibility in xylan degradation; this could have a role in removing side-chains from the complex natural substrate, where different residues are widely present, such as in arabinoxylan. Some xylanases are reported to be arabinose-liberating (Matte \& Forsberg, 1992; Grabski \& Jeffries, 1991), while other xylanases do not liberate arabinose from the main xylan chain (Dekker \& Richards, 1976). Thus, the hydrolysis of arabinogalactan in this case may reflect merely the slow release of arabinose therefrom, though further work would be required to establish this. Two xylanase genes have now been cloned and expressed in this laboratory. Characterization of the expressed xylanases in $E$. coli will allow clarification of their substrate specificities and this work will be reported later.

This work was part of a programme supported jointly by the Agricultural and Food Research Council and Venture Research International. P. Wang thanks the Chinese Academy of Science for a scholarship. We thank A. J. McCarthy and the late M. P. Coughlan for their comments.

\section{References}

Biely, P., Mislovicova, D. \& Toman, R. (1985). Soluble chromogenic substrates for assay of endo-1.4- $\beta$-xylanases and endo-1,4glucanases. Analytical Biochemistry 144, 142-146.

BRADFORD, M. M. (1976). A rapid and sensitive method for the quantitation of microgram quantities of protein utilizing the principle of protein-dye binding. Analytical Biochernistry 72, 248-254. 
Broda, P., Sims, P. F. G. \& MAson, J. C. (1989). Lignin degradation a molecular biological approach. Essays in Biochemistry 24, 82-114.

Buchert, J., Ranua, M., Kantelinen, A. \& Vitkari, L. (1992). The role of two Trichoderma reesei xylanases in the bleaching of pure Kraft pulp. Applied Microbiology and Biotechnology 37, 825-829.

DekKer, R. F. H. \& RICHARDS, G. N. (1976). Hemicellulases: their occurrence, purification, properties, and mode of action. Advances in Carbohydrate Chemistry and Biochemistry 32, 277-352.

Grabski, A. C. \& Jefrries, T. W. (1991). Production, purification and characterization of $\beta$-(1-4)-endoxylanase of Streptomyces roseiscleroticus. Applied and Environmental Microbiology 57, 987-992.

LAEMMLI, U.K. (1970). Cleavage of structural proteins during the assembly of the head of bacterial phage T4. Nature, London 227. $680-685$

Mason, J. C. (1988). HPLC analysis of solubilised products from lignocellulose degradation by actinomycetes. Biotechnology Techniques 2, 95-100.

Mason, J. C., Ruchards, M., Zimmermann, W. \& Broda, P. (1988). Identification of extracellular protein from actinomycetes responsible for the solubilisation of lignocellulose. Applied Microbiology and Biotechnology 28, 276-280.

Matte, A. \& Forsberg, C. W. (1992). Purification, characterization and mode of action of endoxylanases 1 and 2 from Fibrobacter succinogenes S85. Applied and Environmental Microbiology 58, $157-168$
MCCARTHY, A. J. \& BRODA, P. (1984). Screening for lignin-degrading actinomycetes and characterization of their activity against $\left[{ }^{14} \mathrm{C}\right]$ lignin-labelled wheat lignocellulose. Journal of General Microbiology 130, 2905-2913.

MOPPER, R. \& GINDLER, J. M. (1973). A new noncorrosive dye reagent for automatic sugar chromatography. Analytical Biochemistry 56 , $440-442$.

SINNER, M. \& PULS, J. (1978). Non-corrosive dye reagent for detection of reducing sugar in borate complex ion-exchange chromatography. Journal of Chromatography 156, 197-204.

Timell, T. E. (1967). Recent progress in the chemistry of wood hemicelluloses. Wood Scientific Technology 1, 45-70.

Tuohy, M. G. \& Coughlan, M. P. (1992). Production of thermostable xylan-degrading enzymes by Talaromyces emersonii. Bioresource Technology 39, 131-137.

WANG, P. \& BRODA, P. (1992). Stable defined substrate for turbidimetric assay of endoxylanase. Applied and Environmental Microbiology 58 3433-3436.

ZimmermanN, W. \& Broda, P. (1989). Utilisation of lignocellulose from barley straw by actinomyces. Applied Microbiology and Biotechnology 30, 103-109.

ZimmermanN, W., Winter, B. \& Broda, P. (1988). Xylanolytic enzyme activities produced by mesophilic and thermophilic actinomycetes grown on graminaceous xylan and lignocellulose. FEMS Microbiology Letters 55, 181-186. 